Arq. Bras. Med. Vet. Zootec. v.56, n.1, p.116-118, 2004

\title{
Communication
}

[Comunicação]

\section{Evaluation of cefepime kinetic variables and milk production volume in goats}

[Avaliação das variáveis cinéticas de cefepime e da produção de leite em cabras]

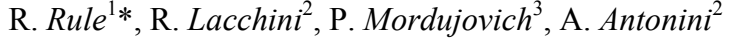 \\ ${ }^{1}$ Comisión de Investigaciones Científicas de la Provincia de Buenos Aires \\ ${ }^{2}$ Cátedra de Introdución a la Zootecnia, Facultad de Ciencias Agrarias e Forestales \\ Universidad Nacional de La Plata, Argentina \\ Calle 60 y 120. 1900. La Plata, Argentina \\ ${ }^{3}$ Cátedra de Farmacologia, Facultad de Ciencias Médicas \\ Universidad Nacional de La Plata
}

Cefepime is a fourth-generation cephalosporin presenting a wider antibacterial spectrum than third-generation cepahlosporins, and decreased susceptibility to $\beta$-lactam hydrolysis. Cefepime can be used for infections that are resistant to old generation cephalosporins, and for septicemy, as well as respiratory, urinary, intra-abdominal, and cutaneous infections. Cefepime is considered a broad spectrum drug, and shows an excellent activity against Escherichia coli, Klebsiella pneumoniae, Pseudomonas aeruginosa, Enterococcus cloacae, Staphylococcus aureus and Estreptococos spp. (Barradell, Bryson, 1994).

The objective of the present work was to investigate the correlation between the kinetic variables, and the volume of milk production, with and without a local inflammatory reaction induced by subcutaneous implants of a device for collecting tissue fluid.

Ten healthy goats, with an average somatic cell counting of $299.000 \pm 193.000$ cells $/ \mathrm{ml}$ of milk (mean \pm SD) were used, and manually milked twice a day. Each animal was subcutaneously implanted with six devices, similar to cages, of a inert material, measuring $10 \mathrm{~cm}$ long by $1,5 \mathrm{~cm}$ wide, with closed ends, and $40 \%$ of perforation in the surface.

Samples of blood and tissue fluid were obtained once a week after the implantation of the collecting devices, during eight weeks. In order to assess the organisms reaction to the implant, total protein and albumin concentrations were determined by biuret reaction, and by method of dye binding using bromosulfoftalein.

The antibiotic cefepime was administered by intravenous (IV; right jugular vein), and by intramuscular (IM; semitendinosus muscle) route, once a week, with single doses of $20 \mathrm{mg} / \mathrm{kg}$ of body weight. Blood samples were collected from all the animals at $0: 10,0: 15,0: 30,1,2,3,4$, $5,6,8$, and 12 hours after drug administration. Milk sampling, of $1 \mathrm{ml}$, followed the same schedule, but started at 15 minutes after drug administration. The blood samples were clotted, followed by a centrifugation at $1000 \mathrm{~g}$ for $5 \mathrm{~min}$, to separate the serum. The samples were then stored in sterilized recipients, at $-18^{\circ} \mathrm{C}$, until analyzed. Antibiotic was detected by a biological method based on Bacillus stearothermophilus var. calidolactis (Lennette, 1987).

Recebido para publicação em 5 de dezembro de 2001

Recebido para publicação, após modificações, em 11 de setembro de 2003

*Corresponding address:

Calle 63 Nro. 216 (1900), La Plata, Argentina

E-mail: robertorule@yahoo.com.ar 
The kinetic analysis was done by calculation of the areas under the curves (AUC) using a trapezoidal method, and the results were used to estimate de bioavailability (f) $[\mathrm{f}=$ AUC(IM)/AUC(IV)], and the passage of the drug into milk (PIM), where PIM= AUC(milk)/AUC(serum)] (Gibaldi, 1991). Cefepime's peaks concentrations in serum and milk $\left(\mathrm{C}_{\max }\right)$, and the time at which it was reached $\left(t_{\max }\right)$ were calculated by using the following formulas:

$C_{\max }=\frac{\ln \mathrm{Ka} / \mathrm{Ke}}{\mathrm{Ka}-\mathrm{Ke}}$, where

$\mathrm{Ka}$ is the rate constant of absorption, and $\mathrm{Ke}$ is the rate constant of elimination, and

$\mathrm{T}_{\max }=\frac{\mathrm{fe}^{- \text {Ke.t max }}}{\mathrm{Vz}}$, where

$\mathrm{Vz}$ is the apparent volume of distribution (Gibaldi, 1991)

A descriptive study of the kinetic and productive variables was performed, and the total and partial correlations between such variables were assessed (Stell, Torrie, 1993). The kinetic variables, and the proteins were analysed by analysis of variance. The level of significance was $5 \%$.
Significant differences $(\mathrm{P}<0.05)$ were observed in the ratio of total proteins from tissue fluid in relation to total proteins from serum between $\mathrm{T} 1$ and T2 (respectively, $83.8 \%$ and $67.5 \%$ ).

Daily milk productions (mean \pm SD) were (T1) $\mathrm{IV}=893 \pm 94$, and $\mathrm{IM}=858 \pm 64$; (T2) $\mathrm{IV}=892 \pm 75$, and $\mathrm{IM}=796 \pm 124 \mathrm{ml}$.

Serum and milk concentrations of cefepime after administration by IV and IM route for both treatments are described in Table 1.

Table 1. Serum and milk concentration of cefepime after its intravenous (IV) and intramuscular (IM) administration in lactating goats (average of T1 and T2)

\begin{tabular}{lccccc}
\hline \multirow{2}{*}{ Time (h) } & \multicolumn{2}{c}{ Concentration of cefepime } & & \multicolumn{2}{c}{$(\mathrm{ug} / \mathrm{ml})$} \\
\cline { 2 - 3 } \cline { 2 - 3 } \cline { 5 - 6 } & \multicolumn{3}{c}{ IV } & & \multicolumn{2}{c}{ IM } \\
\hline 0.25 & 46.25 & 0.25 & & 22.6 & 1.25 \\
2 & 9.1 & 0.65 & & 14.8 & 0.55 \\
8 & 0.75 & 0.30 & & 0.85 & 0.40 \\
12 & 0.35 & 0.17 & & 0.45 & 0.25 \\
\hline
\end{tabular}

Serum and milk kinetic variables of cefepinme administered by IV and IM routes in lactating goats are shown in Table 2.

Table 2. Pharmacokinetic variables in serum (S) and milk (M) of cefepime (mean $\pm \mathrm{SD}$ ) adiministered by intravenous (IV) and intramuscular (IM) routes $(20 \mathrm{mg} / \mathrm{kg})$ to lactating goats $(\mathrm{n}=10)$

\begin{tabular}{lccccc}
\hline \multirow{2}{*}{ Variable } & Trial 1 & \multicolumn{3}{c}{ Trial 2 } \\
\cline { 2 - 3 } \cline { 5 - 6 } AUC(S) $[(\mu \mathrm{g} / \mathrm{ml}) /]$ & $98.5 \pm 16.7$ & IM & & IV & IM \\
AUC $(\mathrm{M})[(\mu \mathrm{g} / \mathrm{ml}) / \mathrm{h}]$ & $8.7 \pm 6.1$ & $2.5 \pm 12.6$ & & $68.5 \pm 33.6$ & $95.7 \pm 38.8$ \\
$\mathrm{~T}_{\max }(\mathrm{M})(\mathrm{h})$ & $0.6 \pm 0.4$ & $6.2 \pm 2.5$ & & $6.7 \pm 2.5$ & $11.8 \pm 8.5$ \\
$\mathrm{C}_{\max }(\mathrm{M})(\mu \mathrm{g} / \mathrm{ml})$ & $8.7 \pm 5.0$ & $2.2 \pm 0.7$ & & $2.0 \pm 1.1$ & $3.6 \pm 0.6$ \\
Penetration $(\mathrm{M})(\%)$ & $0.6 \pm 0.5$ & & $0.7 \pm 0.6$ & $0.6 \pm 0.3$ \\
\hline
\end{tabular}

$\mathrm{AUC}=$ areas under the curves; $\mathrm{t}_{\max }=$ maximum time; $\mathrm{C}_{\max }=$ maximum concentration.

After parenteral administration of cefepime, by IV and IM routes, in lactating goats, with and without local inflammatory reaction (using TCF implant), it was observed that the passage to the mammary gland, $\mathrm{C}_{\max }, \mathrm{t}_{\max }$, and the AUC of the cefepime in milk were independent of route of administration and time of sampling.

When cefepime was administered by IM route, its $\mathrm{C}_{\max }$ in milk was highly correlated with its passage to the mammary gland. Though the AUC in milk is independent of the moment at which
$\mathrm{C}_{\max }$ is reached (an earlier $\mathrm{C}_{\max }$ does not necessarily mean a greater AUC), under IV conditions, significant correlations were observed between AUC milk and $\mathrm{t}_{\max }(\mathrm{r}=0.75$, and $\mathrm{P}=0.001 ; \mathrm{r}=0.97$ and $\mathrm{P}=0.001$, for $\mathrm{T} 1$ and $\mathrm{T} 2$, respectively).

The times at which $\mathrm{C}_{\max }$ appeared in milk were correlated with cefepime's AUC in serum after the IM administration $(\mathrm{r}=0.77$, and $\mathrm{P}=0.001$; $\mathrm{r}=0.59$ and $\mathrm{P}=0.05$, for $\mathrm{T} 1$ and $\mathrm{T} 2$, respectively). 
It is generally accepted that $\mathrm{C}_{\max }$ is proportional to the amount of antibiotic that diffuses into milk, and $t_{\max }$ depends on the rate of such process. The AUC is proportional to the amount of drug that reaches the mammary gland, and is not related to the rate at which it enters the gland (Rule et al., 2000).

Daily volumes of milk production, obtained under $\mathrm{T} 1$ an $\mathrm{T} 2$, did not show a significant correlation with the kinetic variables. This could be explained by the low volume of milk production of the animals employed in the experiment, compared to dairy cows, which receive another cephalosporin called ceftazidime, chemically related to cefepime (Rule et al.,
1996). In lactating cows, the pharmacokinetic profile in the serum after parenteral administration is different when compared to nonlactating cows. In lactating cows, the mammary gland can act as a compartment that traps the antibiotic in the milk.

Concluding, though the penetration of cefepime into milk was low (less than 10\%), the holding time for milk should be observed. The time for discard should be taken into account when using cefepime, in order to avoid problems affecting public health and the dairy industry.

Keywords: cefepime, goat, kinetic, milk, production

\section{RESUMO}

Avaliaram-se as variáveis cinéticas da cefepime e a produção de leite de cabras após a administração parenteral (intravenosa e intramuscular) de cefepime, com e sem reação inflamatória na região implantada. Dez cabras em lactação, implantadas com caixas de material sem reação imunológica para colher o fluido de tecido (FT) foram usadas em dois experimentos. No primeiro a aplicação de cefepime foi feita na primeira semana após a implantação e no segundo na oitava semana. Na primeira semana após a implantação observou-se elevação dos níveis de proteína no fluido do tecido após uma simples dose de 20mg/kg de cefepime via endovenosa ou intramuscular. Amostras do sangue e do leite foram obtidas e as variáveis cinéticas foram avaliadas.

Palavras-chave: cefepime, cabra, cinética, produção de leite

\section{REFERENCES}

BARRADEL, L.B.; BRYSON, H.M. Cefepime. A review of this antibacterial activity, pharmacokinetic properties and therapeutic use. Drugs, v. 47, p.471-505, 1994.

BARZA, M. Principles of tissue penetration of antibiotics. J. Antimicrobiol. Chemother., v.8, parte C, p.7-28, 1981.

GIBALDI, M. Biopharmaceutics and clinical pharmacokinetics. Philadelphia: Lea \& Febiger, 1991. 404p.
LENNETE, E.H. Manual de microbiologia clínica. Buenos Aires: Editorial Medica Panamericana, 1987. 1250p.

RULE, R.; LACCHINI, R.; QUIROGA, G. et al. Pharmacokinetics and penetration into tissue fluid of ceftzoxime in normal and hyperthermic sheep. Small Rumin. Res., v.37, p.43-49, 2000.

RULE, R.; QUIROGA, G.H.; RUBIO, M. et al. The pharmacokinetics of ceftazidime in lactating and non-lactating cows. Vet. Res. Commun., v.20, p.543-550, 1996.

STEEL, R.G.D.; TORRIE, J.H. Bioestadística. Principios y procedimientos. McGRAW-HILL, 1993. 622p. 